\title{
$\frac{2}{16824}$
}

Sammlung Metzler Band 247 


$$
\text { Roy C. Cowen }
$$

\section{Das deutsche Drama im 19. Jahrhundert}

\section{J. B. Metzlersche Verlagsbuchhandlung Stuttgart}




\section{Für meine Frau Hildegard}

\section{CIP-Titelaufnahme der Deutschen Bibliothek}

Cowen, Roy C.:

Das deutsche Drama im 19. Jahrhundert /

Roy C. Cowen. -

Stuttgart : Metzler, 1988

(Sammlung Metzler ; Bd. 247)

ISBN 978-3-476-10247-8

NE: GT

ISBN 978-3-476-10247-8

ISBN 978-3-476-03949-1 (eBook)

DOI 10.1007/978-3-476-03949-1

ISSN 0558-3667

\section{SM 247}

Dieses Werk einschließlich aller seiner Teile ist urheberrechtlich geschützt. Jede Verwertung außerhalb der engen Grenzen des Urheberrechtsgesetzes ist ohne Zustimmung des Verlages unzulässig und strafbar. Das gilt insbesondere für Vervielfältigungen, Übersetzungen, Mikroverfilmungen und die Einspeicherung und Verarbeitung in elektronischen Systemen.

(C) 1988 Springer-Verlag GmbH Deutschland

Ursprünglich erschienen bei J. B. Metzlersche Verlagsbuchhandlung und Carl Ernst Poeschel Verlag GmbH in Stuttgart 1988 


\section{Inhalt}

\section{Einleitung}

1. Zum Zeitraum 1815-1900 ............. 1

2. Zu den Problemen ............... 9

II. Das Drama des Biedermeier bzw. Vormärz (1815-1848)

1. Biedermeierzeit oder Vormärz? . . . . . . . . . . 19

2. Theoretische und nichtliterarische Voraussetzungen .............. 23

3. Das Modedrama, dessen Formen, Stoffe und Vertreter .................. 35

4. Das Drama des soziopolitischen Protests . . . . . $\quad 52$

5. Grabbe ................ 70

6. Büchner . . . . . . . . . . . . . 79

III. Die österreichische Tradition und das Volkstheater bis zum Tod Nestroys

1. Zur österreichischen Tradition .......... 89

2. Grillparzer .................. 100

3. Raimund ................... 109

4. Nestroy . . . . . . . . . . . . . . . 118

IV. Hebbel und das Drama bis zum Naturalismus (1841-1889)

1. Hebbel . . . . . . . . . . . . . . . . . . 127

2. Das Drama im Zeitalter der Prosa: Hettner, Ludwig, Freytag und die Poetischen Realisten . . . . 138

3. Die konservative »Politisierung « des Dramas im Nachmärz und in der Gründerzeit . . . . . . . . . 146

4. Das Revolutionsdrama und Arbeitertheater im Nachmärz . . . . . . . . . . . . . . . . . 157

5. Wagner und die Mythologisierung des Dramas . . 165

6. Österreich nach Nestroys Tod . . . . . . . . . . . 179 
V. Der Naturalismus und dessen Gegenströmungen (1889-1900)

1. Das Drama im Ausland . . . . . . . . . . . . 190

2. Der Weg zum naturalistischen Drama . . . . . . 195

3. Leistungen und Ende des naturalistischen Dramas . 203

VI. Anhang

Benutzte Ausgaben einzelner Dichter . . . . . . . 212

Bibliographie . . . . . . . . . . . . . 213

A. Anthologien und Dokumentensammlungen . . . . . . 213

B. Allgemeine Bibliographie . . . . . . . . . . . 214

Personenregister .................. 229 